\title{
BUILDING THE CONCEPT OF HAPPINESS FOR ADULTS FROM PHENOMENOGRAPHY ${ }^{1}$
}

\author{
Construyendo el concepto de felicidad para adultos desde la fenomenografía \\ Emilio Moyano-Díaz *
}

\begin{abstract}
There is a growing interest in psychology and social sciences to study happiness. Studies are predominantly of positivist epistemology where the concept typically is charged -ethicextensively, ignoring the meaning of happiness to people. To unravel this, an observational, descriptive, transversal study of phenomenographic approach and the corresponding method -emic- are reported here. A non-random sample of faculty and personal staff of a University consisting of 164 Chilean adults of both sexes responded voluntarily and anonymously to a brief survey about happiness and their responses were categorized and graphed respectively, with the help of the NVivo and Campstools programs. It was obtained that happiness has a structure of meanings made up of five conceptions: state, have, achievement, be, well-being which are described, and from which a definition of happiness is proposed and finally, a suggestion on how to continue research in this area.
\end{abstract}

Keywords: Happiness, adults, phenomenography, qualitative method.

\footnotetext{
${ }^{1}$ Investigación realizada en el marco del Proyecto Fondecyt No 1131152. Investigador Responsable: Emilio Moyano-Díaz.

* Facultad de Psicología, Grupo de Investigación en Calidad de Vida y Ambientes Saludables, Universidad de Talca. Talca, Chile. Correo electrónico: emoyano@utalca.cl

El autor agradece a la Dra. Tatiana Canales (Universidad de Viña del Mar, Chile) por su aporte al análisis de resultados (NVivo y Cmaptools5) así como por sus comentarios a una primera versión de este artículo.
}

Artículo recibido el 29 de abril de 2016. Aceptado el 18 de mayo de 2016. 


\section{RESUMEN}

Existe un interés creciente en psicología y ciencias sociales por estudiar la felicidad. Los estudios son predominantemente de epistemología positivista, dónde el concepto típicamente es imputado - etic-, ignorándose extensivamente el significado de la felicidad para las personas. Para desentrañar éste, se reporta aquí un estudio observacional, descriptivo, transversal, de enfoque emic, y fenomenográfico. Una muestra no aleatoria de funcionarios de una universidad constituida por 164 adultos chilenos de ambos sexos respondió voluntaria y anónimamente una encuesta breve acerca de la felicidad, y sus respuestas fueron categorizadas y graficadas, respectivamente, con la ayuda de los programas NVivo y Cmapstools. Se obtuvo que la felicidad presenta una estructura de significados compuesta por cinco concepciones: estado, tener, logro, estar, bienestar, conformadas por variados aspectos y significados que son descritos, y a partir de lo cual se propone una definición de felicidad para, finalmente, sugerir cómo continuar estudios en esta perspectiva.

Palabras clave: Felicidad, adultos, fenomenografía, método cualitativo.

\section{INTRODUCTION}

The importance acquired by Happiness in todays' public discourse is on increase, as ancient are the reflections regarding the same. This could be perhaps a manifestation of a period characterized by the end of grand stories (Lyotard, 1994), liquid societies (Bauman, 1999), where citizens dedicated to their personal wellbeing, demanding psychic comfort, inner harmony and subjective fulfilment (Lipotvetsky, 2007).

The study on happiness has ceased to be exclusive of philosophers and humanists definitively during the second half of the twentieth century, period to which we could fix the beginning of its approach by social science, psychology and economy principally (Argyle, 1992; Seligman, 2002). More recently, verifying the importance of happiness among a group of 55 values and topics, Angelucci, Juárez, Dakduk, Lezama, Moreno and Serrano (2008) requested 3384 Venezuelan university students to indicate the importance that they gave to each one, in an answer format of 1 (not important) to 6 (very important). Among the first five topics, an average close to 6 points, happiness was found in second place after the family, followed by respect, health and honesty. Other studies have identified some factors to which the happiness seems to depend and its variations according to socio-demographic variables and some other to other psychological concepts (for these and global synthesis of the topic see, among others, Seligman 2002; Haidt, 2006; Carr, 2007), or those which the youth carry out as behaviour to obtain 
happiness and its efficacy (Tkach \& Lyubomirsky, 2006; Torres, Moyano-Díaz \& Páez, 2014).

Most of the referred studies have positivist epistemological perspective, either they omit or attribute the meaning of the concept, and the answers obtained to questions such as "Considering your life as a whole, "How happy would you say you are? Or How happy are you today? are registered through likert format. The trustable intensity measure is generally obtained in this manner, but the validity is less evident, remaining in the darkness of what is understood as happiness by those participants of these studies.

A review that covers 10 years of production -2000 to 2012, of articles that include the term happiness in its titles and registered in the web of science (ISI, Institute for Scientific Information) belonging to authors of Latin American institutions, shows the existence of 44 publications. In only three of them-Acosta, Rondón \& Lahitte (2008); Höher, Wathier \& Hofheinz (2011); Carvalho Luz \& Martins Amatuzzi (2008) - happiness is studied from within the participants, as emic category, which is unusual, for generally the Latin American authors adopt some definition proper to anglo-north American literature, being rather exceptional to show some effort of conceptual construction that responds to social and historical-cultural of the region. A partial exception towards this is Alarcón (2006), who contributes a proper definition of happiness which however, based on quantitative epistemology and mainly on anglo-north American literature (Moyano-Díaz, 2016).

Among the studies of qualitative epistemological base Acosta et al. (2008) identified the meaning of happiness (and of death) for 83 Cuban nursing students by a reagent: 'say with one word or phrase what happiness means'. The results (percentage not summable) show that it is of a feeling (36\%), a moment (33\%), of love $(33 \%)$, to be loved $(30 \%)$, to achieve a goal $(30 \%)$ and joy $(23.3 \%)$. On the other hand Höher et al. (2011) studied Brazilian schoolers (12 to 20 years) by semi structured survey carrying 14 questions among which are the following; What comes to your mind when you think of happiness? and What is being happy? His concept of happiness is associated in first place to the sensation of wellbeing, pleasure, acceptation, autonomy and in second place the family, while relations and leisure activities appears to be less important. For women happiness is associated to different forms of social relation and for men it is more towards material goods and life conditions. Finally, in a unique study carried out in adults (59 to 65 years), nondirective interview was applied to three noninstitutionalized adults, occupationally active, and later a phenomenological qualitative analysis. The moments of happiness of these are related to family and social contact, the autonomy and the ability to work, providing the work a sense of personal value, self-esteem and wellbeing (Carvalho Luz y Martins Amatuzzi, 2008). 
In summary, i) the psychological studies undertaken by the Latin Americans on happiness and indexed in ISI have not treated the topic from the qualitative epistemology except for a few, ii) the results of the few qualitative studies show that for adolescents happiness is wellbeing, pleasure and autonomy associated to family; a feeling, moments, love and to be loved, reach goals, while for adults, along with family contact, it also covers social contact and autonomy linked with the ability to work, which generates a feeling of worth, self-esteem and wellbeing (Moyano-Díaz, 2016).

Understanding the subjectivity in terms of happiness is not only important theoretically -to advance in the understanding of this powerful human motive- but also has social, political and practical relevance for today's public policy, especially, when the notion of countries development is deduced from indicators traditionally considered from 'development' -gross domestic product (GDB) and equals- is in stake for insufficiency. The benefits expected from economic development (GDB) does not necessarily become wellbeing for the persons (Stiglitz, Sen y Fitoussi, 2008; Stiglitz, Sen \& Fitoussi, 2010) and could be accompanied by the worsening of social indicators (Giarrizo, 2011; Zarur, 2011) till, in the case of Chilean economic development, correlate strong and significantly with suicide (Moyano \& Barría, 2006). Thus, new concepts and measurements are required to effectively make known the subjectivity of persons and psychology could powerfully contribute with the psychological and subjective wellbeing, vital satisfaction, happiness, or alike. These provide subjective information, powerfully very valuable for the democracies, because at the time of annual report, information that results near and subjectively true or meaningful for citizens and thus, promote progress so as the persons could "feel, live and appreciate"... generating greater empowerment of the people" (Rojas, 2011: 38).

The Phenomenography. Etymologically the word comes from Greek "pháinomenon" or appearance, and "gráphein", writing, logo or description of things, as it is present to the individuals. The object of its study is the variation in meaning, the comprehension and the conception of a particular phenomenon, where the interest is on what the persons thing about it (Marton, 1981) or as it seem to whoever lives (Marton, 1986). Sonnemann in 1954 would have been the first to use the term Phenomenography (Dahlin, 2007), and from the 1970s Swedish authors apply the term to the understanding of the concept "learning" in student and professors (Marton, 1981; 1988; Eklund-Mirkskog, 1988; Tsai, 2004; Virtanen \& Lindblom-Ylanne, 2010). Thus, seven conceptions of "to learn" has been identified in the students: to increase the knowledge, memorize, to apply, to understand, to see things differently, to change as person (Marton, Dall'Alba \& Beaty, 1993; Saljo, 1979) and fulfilment (Purdie, Hattiey Douglas, 1996), conceptions rediscovered by Rosario, Gracio, Nuñez, Gonzáles-Pendia (2006). Other studies have pointed out the significance of learning of specific disciplines: 
Engineering (Marshall, Summer, \& Woolnough, 1999), Biosciences (Virtanen \& Lindblom-Ylánne, 2010), marketing (Hung-Ming \& Han-Jen, 2011).

The Phenomenography method is the empirical study of qualitative changes in ways in which a group of persons experience a phenomenon (Ashwin, 2005), where the researcher assumes a perspective proper to the persons researched, being a focus of second order to capture as the world is constructed and represented by its actors (Rosario et al. 2006). The semi-structured interview is the technic mostly used in phenomenography, but could be changed according to the phenomenon, the question, and the context of research. In order to provoke the participants the questions are direct; what is for you...? (Happiness in this case), How do you experience...? (Booth, 2008), and alike.

It is accepted that there is a limited number of ways through which the persons interpret the phenomenon analyzed, and the purpose is to capture and observe its variations (Åkerlind, 2005). The narrative obtained is transcribed and analyzed from undefined analytical -descriptive categories, but the same text emerges by means of interaction with the researcher and its interpretation which will shape conceptions. The researcher analysis and organizes the information using logical criteria of amplitude or inclusion of significance (Marton \& Yan Pong, 2005) and produce a graphical representation of the same.

A 'conception' may be characterized as composed of two aspects, one referential, corresponding to the particular object in question, and the other structural that is the combination of the discerned features and focused from and by the subject from the object (Marton \& Yan Pong, 2005). These authors propose the theory of variation to supplement the phenomenographic perspective, focusing on the structural aspect of conception. To produce meaning or to have a conception always presupposes discernment and this variation (Marton \& Tsui, 2004). In Phenomenography what interests especially are the communicative validity and the pragmatic validity, where the first refers to the ability of the researcher to produce plausible interpretations, while the second refers to the degree to which the test result is considered useful and meaningful to his audience (Åkerlind 2005).

In the present study, a phenomenography perspective is adopted, to make intelligible those that are unknown, what is the meaning of happiness for adults, progressing on what has been explored for other age sections and sample coverage. The purpose is to contribute to the knowledge of meaning of happiness in adults by using a qualitative focus and a phenomenographic methodological approach. Additionally, the application online (internet) of an alternative instrument to the semi-structured interview, and whose answers are written, allows access to a greater number of participants that are common in such phenomenographic research and, also, expand the coverage of variations of the responses or different meanings given to the phenomenon. 


\section{METHOD}

Observational, cross-sectional study aimed to identify sets or types of meaning that participants have about happiness and express through answers or self-report. It seeks to identify the meaning, knowledge, experience, meaning, emotions, and general conceptions that participants have of happiness.

\section{PARTICIPANTS}

820 staffs from a state university in Chile were invited by email to participate voluntarily and anonymously to answer a short survey on happiness. Thus, a sample of 164 adults, 92 men and 72 women of average 45.2 years (DS 10,3) was constituted. Of these, 115 are academics (19 in administrative management functions) and 49 administrative, mostly employed (84.7\%) full time. Their educational level ranges from technical and vocational training (secretaries \& Assistants) to post doctorate (Academics).

Instruments. For the phenomenography the only way to access the experiences of people is self-report (Marton \& Booth, 1997) and so a survey of 5 items was elaborated preceded by an invitation to participate anonymously in research on happiness, with informed consent explaining the possibility of interrupting the participation although it had begun, and the interest was for the results of the whole sample. Information on sex, age, membership (academic or administrative), type of contract (full, half or three quarters and hourly), and answer to the question "What is for happiness for you?" without limitation of time or space for text. The survey was applied online (Google doc) and the responses were analyzed with the help of NVivo program and its graphic representation through CmapTools 5.

Procedure. As per the phenomenographic method the first reading of the obtained results followed the procedures of open coding and in this case with the help of NVivo software, the search for structural relation between them was complemented. Later the coded meanings were analyzed seeking to configure in terms of structure and variation or differentiation. The idea was taken as the unit of analysis, being encoded just as synonymous words. Modeling or illustration of the final map was constructed with the help of software CmapTools 5. 


\section{RESULTS}

The responses and meaning given by the participants about happiness allows to unveil five lines of description or conceptions: happiness as 'state' (of being), happiness as 'to have', happiness as 'achievement', happiness as 'being', and happiness as 'wellbeing' all of which are defined below.

1. Happiness as "State". Most of the responses or meanings of the sample participants corresponds to this concept. Happiness is considered here as a mental, transient, balancing feature. This state has variations of meaning, according to the consideration that it is something ephemeral or more permanent: sensation or feeling, a mood or of balance or also as per the elements that can contribute to such a state. A sample answer of this conception, happiness is: "A passenger state of intense satisfaction and harmony with those around you, yourself, and the environment," or "The happiness is a state of fullness and absolute temporary satisfaction”.

2. Happiness as "to have". Here the answers are grouped which define happiness as property, recognition of certain characteristics, opportunities, or relevant aspects that are considered favorable or positive for life. In this category happiness is conceived as having good physical and mental health, have free time, have a healthy family in harmonious relationship or have a well-paid job, stable, generating positive experiences and free time. Ex.: "For me happiness is achieved when having a content, well-formed and peaceful family, good health, stable and timely paid job and have labor and family challenges that would keep my mind active".

3. Happiness as "achievement". Ideas that consider happiness as a result of certain behaviors or internal and external conditions that generate a positive feeling associated with achievement are grouped here. Especially relevant and repetitive among the participants is the idea of happiness as satisfaction in achieving goals obtained either individually or also by the group or groups to which the person has the sense of belonging. Also in this conception of happiness lies the fact to know or value - that one has done things well and that the efforts have been worthwhile. Ex. happiness is: "A state of transient mood that arises from achieving personal goals or the group to which one belongs".

4. Happiness as "being". Answers that consider happiness as an assessment of the status of physical position - or eventually symbolic- of the person against his own life are grouped here. Generally these meaning include a strong association with places or people who generate satisfaction. The mentioned territorial and symbolic place corresponds to home, being surrounded by the loved ones, being in/with freedom and power to carry out joyful activities. Ex. happiness is: not a "to be" happy, but "being" happy in different circumstances of life. 
5. Happiness as "Wellbeing". Ideas that do not refer directly to happiness as it is, but refer to a variety of status or related components to the same are grouped here. These can be considered as influential or eventually determining aspects of happiness. Thus, terms such as tranquility, peace, stability, and wellbeing are used in different spheres of human functioning: economic, physical, psychological and social. Ex. "I consider happiness as a state in which I am fine in family, social, emotional, work and mental environment". Well-being and its main foci of meaning in each one (rectangles).

Follows is our map of meaning (Fig.1) or global mental model representation of happiness, with its structure of five conceptions (in dark ovals); state, have, achievement, being, well-beings. Those sub-components that make them up are located inside of these and represent variation in meaning.

Figure 1. The pentagon of happiness: structure and meaning of concept

$$
(\mathrm{n}=164 \text { adults, } \mathrm{M}=45.2 \text { years of age })
$$

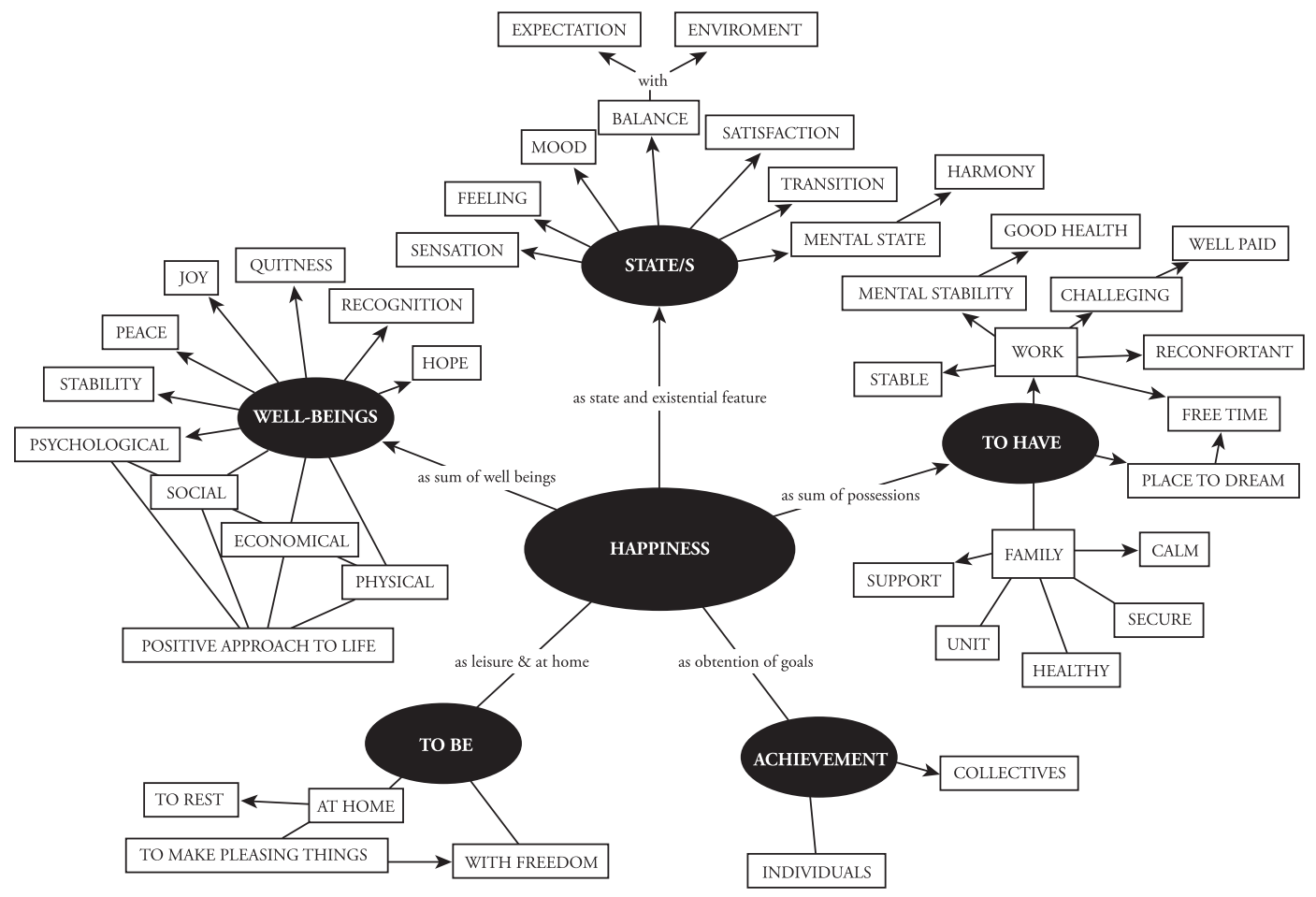

The analysis of the foci of the contents of illustration (rectangles) in each conception allow to observe certain founding or anchoring concepts, such as the term (state) of mind to State, with a double meaning according to its degree of durability, state (temporary, ephemeral), or feature (of greater permanence), as sensation or feeling. In the concepts of family and work-adjectives-contents in the concepts of happiness as to Have and, in the goals, featured as happiness like Achievement. 
In turn, the concept of happiness as Being is supported by a mixture of different components such as home-house, rest, freedom, leisure. Finally, the foci in the concept called Wellbeing, refers to being fine with stability, in physical, economic, psychological and social environment, including a variety of conditions: peace-tranquility, hope, recognition and joy, all leading to a positive outlook of life.

There are clear intersections between certain concepts (not plotted in the pentagon): to have family and work, positively valued that share some degree of overlapping with being in family. Thus, the existence of the family support is mentioned frequently, to see the children healthy and happy, but very especially, in this sample, the fact of Being or sharing in family as producer of enjoyment. Another central component of to Have is the job, and when it meets certain requirements also seems to give -besides economic security and stability(Wellbeing), the feeling of Achievement (goals) individual and collective, and recognition among its clearest effects.

It is remarkable that among the results, the generalized omission of the social aspects regarding cultivating friendship or the social relations beyond the family group or the social participation in general in relation to happiness and, when they appear, they do only incidentally.

An effort of integration of all conceptions and its founding or foci concepts, enables an elaboration of the following definition of happiness: A state more or less transient of balance, related to conditions, results or individual or group achievements favorable or rewarding to persons, usually associated to a sense of satisfaction and wellbeing. This condition arises based on the stability of certain elements relevant to the person, security, and basic support in terms of economic (work) and family, which enables to freely dedicate to activities that involve possibilities of enjoyment, development and fulfillment.

\section{DISCUSSION AND CONCLUSIONS}

We have identified five conceptions of happiness that adults have, and that can be arranged in their corresponding five structural components, from which a definition of happiness emic (or participants) has been generated. It seems implicit in the definition proposed the presence of two classical theoretical approaches that have disputed in the field of literature on wellbeing and happiness in psychology; hedonism and eudaimonia (Ryan \& Deci, 2001).

El hedonism is explicit ('Pleasant things') in the conception Being, but can also be re-found in work that is proper to Have, when that has certain features such as inner motivation and to be (work) challenging, and we thought that effectively most of the sample have had it. On the other hand, the achievement of goals 
-individuals or collective- proper to the conception Achievement corresponds more to the Eudaimonia (Beatitude) as well as the own meaning of State are close to it.

We think that the proposed definition of happiness allows to overcome the antinomy hedonism (joy) versus Eudaimonia (duty-beatitude- and transcendental achievements), when integrating dialectically both concepts. Perhaps it is the flow -the total involvement in a felt activity as very pleasurable (Csikszentmihalyi, 1998) - the catalyst and inclusive of both, and simultaneously operating in both.

Happiness for this group of adults is understood in different way but finite, and of clear limits though twisty for its crosslinking's, but it is clear that most participants mean happiness as a State. This conception as psychological category is of higher level abstraction than the other four, which may be due to the educational level that is above the national average of this sample. The conception to Have for example, has more materials than specific contents (mainly have family and work). It also happens with the conception of one's own happiness of Achievement for it shares with that of Have, its reference to questions and external objects to the individual, and whose character seems relatively of great permanence than those referred to in State.

The State and to Have as conceptions of happiness produces two dimensions - to be and to have- that were proposed as "... two fundamental modes of experience, the forces that determines the difference between the individuals and the different types of social characters" (Fromm, 1984: 33-34). From this approach of Fromm so far however we have learnt on one hand, the inextricable link between the psychological and the social (Diaz Gómez \& González Rey, 2010; Hernández, 2008) and, on another hand a common effect of the endless supply of 'consumer-happiness' typical of the hyper consumer societies and this is deception and boredom in many 'turbo-consumers' (Lipotvestky, 2008) either be it by the inability of these to consume everything or be it for the difficulty to decide 'good' between other options that which easily ends in regret (Schwartz, Ward, Monterosso, Luybomirsk, White, Lehman, 2002; Moyano, Cornejo, Carreño \& Muñoz, 2013), or for the volatile sensation of satisfaction or the wellbeing produced by the buying and consumption (Csikszentmihalyi, 1998).

A characteristic attributable here to the contents of conception Have is its intimate or private character for the participants. This is what happens with have 'mental stability' or 'space to dream' which are also convergent with being in 'harmony or in balance', that which are specific contents of the conception Being. Also belongs to the private sphere of the family to which, moreover, constituting with the work the two great foci if Have, does not seem to be related among each other, rather as two independent worlds on the topic.

The analysis of variations also allows to observe a group of persons to whom the concept of happiness is not clearly distinguishable in respect to other 
phenomenon (well-being), and also have expressed that it has been difficult to respond to the question of what is happiness but yet ended up answering. Their responses refers to other psychological state -tranquility, peace, stability, wellbeing in different domains-, but can influence or to certain extent be overlapped with, or eventually can determine the happiness, all of which invites further research.

While for some persons happiness is essentially a phenomenon of within (inner life), an existential state and mental harmony, balance and satisfaction, for others, turned towards outside, it is a result to reach external goals (Achievement). For sure, both conceptions are not exclusive and for most participants the different conceptions coexist, intermingling and overlapping psychologically, existing then feedbacks in variable degree between the activities and consequences that are proper or characteristics of each one. Thus, whoever remains in harmony and balance (that which can vary from the no desire -Buddhist- or resignation -Christianity- or the contemplation, to a pedestrian or common, reasonable and everyday correspondence between expectations and achievements), perhaps more likely to reach goals, for ex. get a job, partner or the desired family, which in turn positively impact on different welfares - physical, economic, social, etc.- and contribute to feedback the state of balance, harmony and initial satisfaction.

These variations of meaning are intermingled in varying degrees in people, giving direction and strength characteristics to the behaviour of each one, in a social subjectivity in which it can frequently end up being complex to make converge individual goals (desires, feelings, emotions, personal reasons) with other type of family, or collective (institutional or ideological projects).

The attempt to reveal the reciprocal influences of meanings between different co-existing conceptions in people and their potential behavioral consequences could perhaps be explored from the perspective of complexity (Hernández, 2008). It would be theoretically and politically useful to count with a revealing and comprehensive reading, each time more profound, of the role of happiness as (motive) a router of individual and collective behavior, and its distinction from the psychological and subjective wellbeing in today's society, increasingly open to the consideration of subjectivity and the corresponding psychological concepts, as indicators of progress and human development.

The larger sample of participants here to what is usual in phenomenographic studies, give assurances as having covered a wider range of possible meanings and conceptions. Among these, it is possible to rediscover the meaning of happiness reported in previous studies, namely: feeling, moments, wellbeing, family contact, achieve goals, work.

One way to continue this line of research and that this can become a way to overcome the limitation of having highly educated participants, is to investigate samples of other educational and socioeconomic levels. Also, a study on the concept 
can be done cross culturally controlling general cultural patterns -individualismcollectivism, for example- that are probably associated with particular forms of relation with or understanding the concept and its references (Rojas \& Vitterso, 2010). Conducting such studies allows to confirm the five conceptions here researched, or identify new conceptions and, in both cases, enrich our knowledge and conceptual theoretical heritage of subjectivity as a cultural historical product, in this issue of growing interest to the peoples and their governments.

\section{REFERENCES}

Acosta, Maritza, Rondón, Juan José y Soler Lahitte, Mercedes. "Percepción de muerte y felicidad en estudiantes de Licenciatura en Enfermería”, Revista Cubana de Enfermería 24/2 (2008): 1-10.

Åkerlind, Gerlese S. "Variation and commonality in phenomenographic research methods", Higher Education 24/4 (2005): 321-334.

Alarcón, Reynaldo (2006). "Desarrollo de una Escala Factorial para medir la felicidad", Revista Interamericana de Psicología 40/1 (2006): 99-106.

Angelucci, Luisa, Juárez, José F., Dakduk, Silvana, Lezama, José, Moreno, Agustín y Serrano, Arturo. "Jerarquía de valores en estudiantes universitarios", Argos 25/48 (2008): 6- 21.

Argyle, Michael. La psicología de la felicidad. Madrid: Alianza, 1992.

Ashwin, Paul. "Variation and commonality in phenomenographic research methods", Higher Education Research \& Development 24 (2005): 321-334.

Bauman, Zigmunt. Modernidad líquida. Buenos Aires: Fondo de Cultura Económica, 1999.

Booth, Shirley. "Researching Learning in Networked Learning-Phenomenography and Variation theory as empirical and theoretical approaches", Proceedings of the 6th International Conference on Networked Learning, (2008): 450-455.

Bowden, J. \& Walsh, E. (eds.). Phenomenographic Research: Variations in Method. (Eds.) Melbourne: RMIT Publishing, 1994. 
Bowden, J. The nature of phenomenographic research. In Bowden, J. \& Walsh, (Eds.), Phenomenography: Qualitative Research Series. Melbourne: RMIT University Press, (2000): 1-19.

Carvalho Luz, Márcia Maria \& Martins Amatuzzi, Mauro. "Vivências de felicidade de pessoas idosas", Estudos de Psicologia, Campinas, 25 /2 (2008): 303-307.

Carr, Alan. Psicología Positiva. La ciencia de la felicidad. Barcelona: Editorial Paidós, 2007.

Csikszentmihalyi, Mihalyi. Fluir. Una psicología de la felicidad. Barcelona: Kairós, 1998.

Dahlin, B. "Enriching the Theoretical Horizons of Phenomenography, Variation Theory and Learning Studies", Scandinavian Journal of Educational Research 51/4 (2007): 327-346.

Eklund-Myrskog, G. Students' conceptions of learning in different educational contexts. Higher Education 35 (1998): 299-316.

Fromm, Erich. ¿Tener o ser? Argentina: Fondo de Cultura Económica, 1984.

Giarrizo, Victoria. Mediciones de bienestar económico: una alternativa para complementar los indicadores de crecimiento. En M. Rojas (Coord.), La Medición del Progreso y del Bienestar. Propuestas desde América Latina. México: Foro Consultivo y Científico Tecnológico, (2011): 143-154.

Haidt, Jonathan. La hipótesis de la felicidad. España: Editorial Gedisa, 2006.

Hernández, Oscar G. "La subjetividad desde la perspectiva histórico-cultural: un tránsito desde el pensamiento dialéctico al pensamiento complejo", Revista Colombiana de Psicología 17 (2008): 147-160.

Höher, Síglia, Wathier, Josiane \& Hofheinz, Claudia. "De que eles precisam para serem felizes? A felicidade na visão de adolescentes", Revista Semestral da Associação Brasileira de Psicologia Escolar e Educacional, SP, 15/2 (2011): 241-250.

Hung-Ming, Lin \&. Han-Jen, Niu. "A Phenomenographic Approach for Exploring Conceptions of Learning Marketing among Undergraduate Students", Business and Economic Research 1/1: E3 (2011): 1-12. 
Lipotvetsky, Gilles. La felicidad paradójica. Ensayo sobre la sociedad de hiperconsumo. Barcelona: Editorial Anagrama, 2008.

Lyotard, Jean-François. La condición posmoderna. Madrid: Cátedra, 1994.

Marshall, D., Summer, M. \& Woolnough, B. “Students' conceptions of learning in an engineering context", Higher Education 38/3 (1999): 291-309.

Marton, F. \& Yang Pong, W. "On the unit of description in phenomenography", Higher Education Research \& Development 24/4 (2005): 335-348.

Marton, F. "Phenomenography. A research approach investigating different understandings of reality", Journal of Thought 21/2 (1986): 28-49.

Marton, F. Phenomenography: Exploring different conceptions of reality. In D. Fetterman (Ed.), Qualitative approaches to evaluation in education: The silent scientific Revolution. New York: Praeger, (1988): 176-289.

Marton, F. \& Tsui, A. B. M. (Eds.). Classroom discourse and the space of learning. Mahwah, NJ: Lawrence Erlbaum, 2004.

Marton, F. "Phenomenography describing conceptions of the world around us", Instructional Science 10 (1981): 177-200.

Marton, F., \& Booth, S. Learning and awareness. Mahwah, NJ: Lawrence Erlbaum, 1997.

Marton, F., Dall'Alba, G. \& Beaty, E. "Conceptions of learning”, International Journal of Educational Research 19 (1993): 277-300.

Moyano-Díaz, Emilio (2016). Trends and challenges for the research of happiness in America Latina. En M. Rojas (Ed.), Handbook of Happiness Research in Latin América. Alemania: Springer, (2016): 63-87.

Moyano-Díaz, Emilio y Barría, Rodolfo. "Suicidio y Producto Interno Bruto (PIB) en Chile: hacia un modelo predictivo", Revista Latinoamericana de Psicología 38/2 (2006): 343-359.

Moyano-Díaz, Emilio, Cornejo, Felipe, Carreño, Marcela y Muñoz, Alejandra. "Bienestar Subjetivo en Maximizadores y Satisfacedores", Terapia Psicológica 31/3 (2013): 273-280. 
Purdie, N., Hattie, J. \& Douglas, G. "Student conceptions of learning and their use of self-regulated learning strategies: A cross-culture comparison", Journal of Educational Psychology 88/1 (1996): 87-100.

Rojas, Mariano \& Vitterso, Joar. "Conceptual Referent for happiness: Cross country Comparisons”, Journal of Social Research \& Policy 2 (2010): 103-116.

Rosário, Pedro, Gracio, María Luisa, Núñez, José Carlos y Gonzalez-Pienda, Júlio "Perspectiva fenomenográfica de las concepciones del aprendizaje", Revista Galego-Portuguesa de Psicoloxía e Educación 13/11-12 (2006): 195-206.

Ryan, R. M. \& Deci, E. L. "On happiness and human potentials: A review of research on hedonic and eudaimonic well-being", Annual Review of Psychology 52 (2001): 141-166.

Säljö, R. Learning in the learner's perspective I. Some commonsense conceptions. Gothenburg, Sweden: Institute of Education, University of Gothenburg, 1979 .

Säljö, Roger. Minding action-conceiving of the world versus participating in cultural practices. In G. Dall'Alba \& B. Hasselgren (Eds.), Reflections on phenomenography, towards a methodology? Goteborg: Acta Universtatis Gothoburgensis, 1996.

Schwartz, Barry, Ward, Andrew, Monterosso, John, Luybomirsky, Sonja, White, Katherine, Lehman, Darrin. "Maximizing Versus Satisficing: Happiness Is a Matter of Choice", Journal of Personality and Social Psychology 83/5 (2002): 1178-1197.

Seligman, Martin. La auténtica felicidad. Barcelona: Ediciones B, 2002.

Stiglitz, J. E., Sen, A., \& Fitoussi, J. Report by the Commission on the Measurement of Economic Performance and Social Progress, 2008.

Stiglitz, H., Sen, A., \& Fitoussi, J. Mis-Measuring Our Lives. Why GDP Doesn't Add Up. New York: The New York Press, 2010.

Svensson, L. "Theoretical foundations of phenomenography", Higher Education Research \& Development 16/2 (1997): 159-171. 
Takch, C. \& Lyubomirsky, S. "How do people pursue happiness? Relating personality happiness-increasing strategies, and well-being", Journal of Happiness Studies 7 (2006): 183-225.

Torres, Mauricio, Moyano-Díaz, Emilio y Páez, Darío. "Comportamiento juvenil universitario en busca de la felicidad y su eficacia”, Universitas Psychologica 13/4 (2014): 1419-1428.

Tsai, C. C. "Conceptions of learning science among high school students in Taiwan: A phenomenographic Analysis", International Journal of Science Education 26 (2004): 1733-1750.

Virtanen, V. \& Lindblom-Ylänne, S. “University students' and teachers' conceptions of teaching and learning in the biosciences", Instructional Science 38/4 (2010): 355-370.

Zarur, G. (2011). Progreso, la producción social de la felicidad. En M. Rojas (Coord.), La Medición del Progreso y del Bienestar. Propuestas desde América Latina. México: Foro Consultivo y Científico Tecnológico, (2011): 265270 . 